ISSN : 2460-3562

\title{
Rancang Bangun Sistem Pengendali Smarthome menggunakan Mikrokontroler dengan Speech Command pada Smarthome Android
}

\author{
Achmad Rafiqi Azka ${ }^{\# 1}$, Elang Derdian Marindani ${ }^{\# 2}$, Rudy Dwi Nyoto ${ }^{\# 3}$ \\ "Program Studi Teknik Informatika Universitas Tanjungpura \\ Jl. Prof. Dr. H. Hadari Nawawi, Pontianak 78124 \\ ${ }^{1}$ mugensai76@gmail.com \\ ${ }^{2}$ elangdmeyahoo.co.id \\ ${ }^{3}$ rudydn@gmail.com
}

\begin{abstract}
Abstrak - Rumah memiliki berbagai macam peralatan listrik dan tak jarang penghuni rumah lupa mematikan peralatan listrik yang telah selesai digunakan, hal ini tentu memiliki beberapa dampak seperti memperpendek umur peralatan listrik, dan apabila dibiarkan terlalu lama dapat memicu terjadinya kebakaran. Saat ini banyak perumahan menengah ke atas yang memodifikasi rumahnya menjadi rumah yang berdaya guna tinggi (Smarthome) dimana penghuni dapat mengendalikan peralatan listrik dan dilengkapi dengan sensor - sensor serta otomatisasi saat terjadi perubahan status sensor. Dalam penelitian ini aplikasi smarthome yang dibuat berkomunikasi melalui alamat ip yang dimiliki oleh mikrokontroler, yang mana aplikasi dapat digunakan untuk melakukan kendali secara manual atau speech recognition, dan dapat memberikan otomatisasi apabila terdapat perubahan kondisi dari status sensor - sensor yang terhubung pada mikrokontroler. Dari hasil pengujian dengan simulator menunjukkan bahwa rancang bangun sistem pengendali smarthome menggunakan mikrokontroler dengan speech command pada smartphone Android yang telah dibuat dapat berjalan dengan baik untuk mengendalikan peralatan listrik dan dapat menampilkan kondisi suhu, kelembapan, cahaya, dan gas.
\end{abstract}

Kata kunci - Android, Smarthome, Mikrokontroler, Sensor, Speech Command.

\section{Pendahuluan}

Rumah memiliki berbagai macam peralatan listrik dan tak jarang penghuni rumah lupa mematikan perlatan listrik yang telah selesai digunakan, hal ini tentu memiliki beberapa dampak seperti memperpendek umur peralatan listrik, dan apabila dibiarkan terlalu lama dapat memicu terjadinya kebakaran.

Saat ini banyak perumahan menengah ke atas yang memodifikasi rumahnya menjadi rumah yang berdaya guna tinggi (Smarthome) dimana penghuni dapat mengendalikan perabotan listrik di dalam rumahnya dan dapat mengendalikan peralatan listrik.
Terdapat beberapa definisi smarthome dari berbagai sudut pandang salah satunya Menurut Nicola King (2003)[1], mendefinisikan smarthome sebagai sebuah hunian yang dilengkapi dengan jaringan komunikasi yang menghubungkan berbagai layanan dan peralatan elektronik, dan memungkinkan untuk dipantau, diakses dan dikendalikan dari jarak jauh, misalnya menggunakan smartphone.

Smartphone yang sedang digandrungi oleh masyarakat adalah smartphone berbasis sistem operasi Android. Salah satu fitur yang disediakan smartphone adalah speech command. Speech command merupakan proses identifikasi untuk mengenali kata yang diucapkan oleh seseorang. Speech command biasa digunakan untuk menggantikan peranan input pada keyboard untuk menjalankan suatu aplikasi pada smartphone atau teknologi lainnya. Selain itu smartphone yang erat kaitannya dengan internet dapat dimanfaatkan untuk mengendalikan mikrokontroler yang terhubung dengan internet seperti Raspberry Pi.

Raspberry Pi adalah komputer mikro berukuran kecil yang dikembangkan oleh Raspberry Pi Foundation, Inggris. Komputer single board ini dikembangkan dengan tujuan untuk mengajarkan dasar-dasar ilmu komputer dan pemrograman untuk siswa sekolah di seluruh dunia. Pada salah satu jurnal dari International Journal of Computing and Technology yang berjudul Android Based Home Automation Using Raspberry Pi menuliskan bahwa dimungkinkan untuk membuat sebuah sistem kendali jarak jauh untuk mengontrol relay menggunakan Raspberry Pi melalui aplikasi Android yang dijalankan pada smartphone yang memakai sistem operasi Android.

\section{URAIAN PENELITIAN}

\section{A. Smarthome}

Smarthome dapat didefinisikan sebagai "Aplikasi gabungan antara teknologi dan pelayanan yang dikhususkan pada lingkungan rumah dengan fungsi tertentu yang bertujuan meningkatkan keamanan, efisiensi 
dan kenyamanan penghuninya. Sistem rumah pintar (Smarthome) biasanya terdiri dari perangkat monitoring , perangkat kontrol dan otomatis ada beberapa perangkat yang dapat diakses menggunakan komputer" [2].

\section{B. Raspberry $\mathrm{Pi}$}

Raspberry Pi merupakan komputer kecil seukuran kartu kredit dengan harga cukup murah yang mampu melakukan berbagai hal seperti Personal Computer (PC), misalnya menjelajah internet, memutar video, memproses dokumen, bahkan bermain game. Raspberry Pi dikembangkan oleh The Raspberry Pi Foundation, sebuah organisasi yang berfokus pada pengembangan pendidikan untuk segala umur, terutama di bidang ilmu komputer[3].

Raspberry Pi 3 berukuran 85,60mm x 56mm dan menggunakan prosesor $1.2 \mathrm{GHz}$ 64-bit quad-core ARM Cortex-A53. Raspberry Pi 3 juga dibekali dengan 802.11n Wireless LAN,Bluetooth 4.1, Bluetooth Low Energy (BLE), 1GB RAM, 4 USB port, 40 GPIO pin, HDMI port, Ethernet port, $3.5 \mathrm{~mm}$ audio jack dan composite video, Camera interface (CSI), Display interface (DSI), Micro SD slot.

\section{PERANCANGAN SiSTEM}

\section{A. Perancangan Arsitektur Sistem}

Arsitektur sistem merupakan gambaran garis besar cara kerja sistem yang digambarkan melalui model - model yang saling berhubungan. Pada Gambar 3.2 digambarkan cara kerja sistem yang saling terhubung

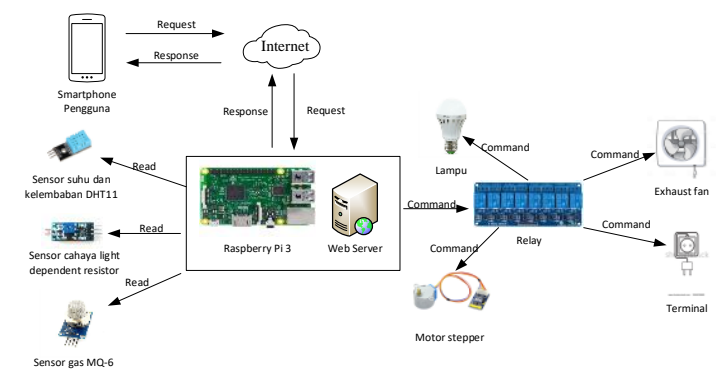

Gambar 1. Desain Arsitektur Sistem

\section{B. Perancangan Struktur Antarmuka Sistem}

Aplikasi yang dibangun merupakan aplikasi yang dirancang pada platform Android. Struktur antarmuka aplikasi yang dirancang dapat dilihat pada gambar berikut:

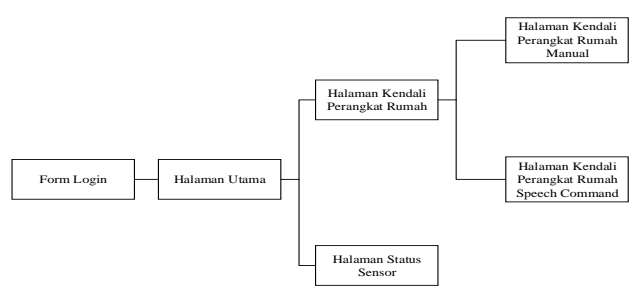

Gambar 2. Struktur Antarmuka Sistem

\section{HASIL PERANCANGAN DAN PENGUJIAN}

\section{A. Perancangan Struktur Antarmuka Sistem}

Berikut merupakan hasil rancangan simulasi alat yang digunakan.

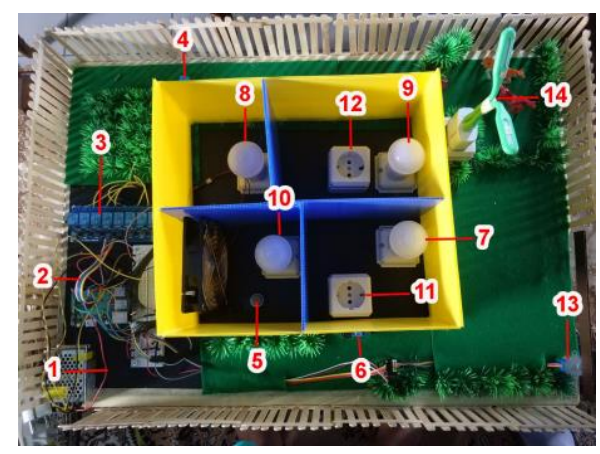

Gambar 3. Perangkat Keras

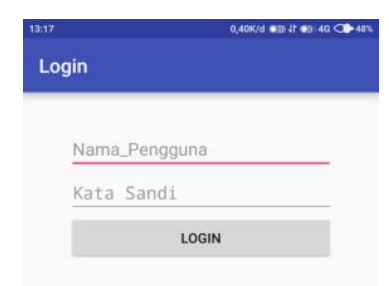

Gambar 4. Halaman Login Aplikasi

\section{B. Antarmuka Aplikasi}

Aplikasi yang dirancang merupakan aplikasi platform Android.Untuk dapat menggunakan aplikasi ini, pengguna diharuskan memasukkan nama pengguna dan kaa sandi pada halaman login.

Setelah validasi login selesai, maka pengguna akan masuk ke halaman menu utama, yang mana dari halaman menu utama ini pengguna dapat mengakses menu yang tersedia selanjutnya, diantaranya menu kontrol perangkat rumah dan status sensor.

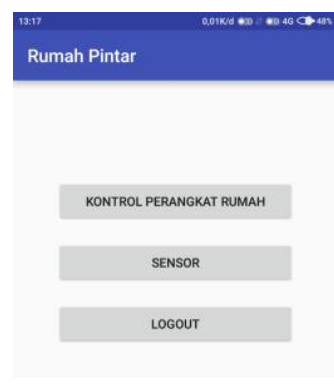

Gambar 5. Halaman Menu Utama Aplikasi 
Pada halaman kontrol perangkat rumah pengguna dapat memilih untuk mengendalikan perangkat rumah dengan cara manual atau dengan cara perintah suara.

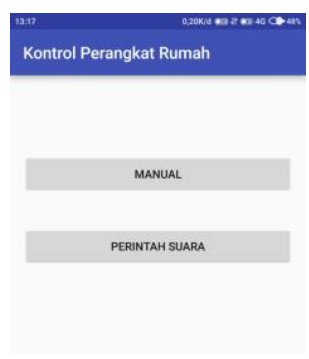

Gambar 6. Halaman Menu Kontrol Peranngkat Rumah

Pada halaman manual pengguna dapat melakukan kontrol terhadap perangkat rumah yang terpasang dengan menekan tombol hidup atau mati.

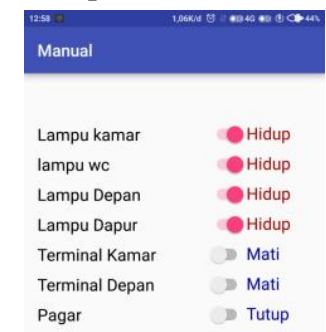

Gambar 7. Halaman Menu Manual

Pada halaman perintah suara pengguna dapat mengendalikan perangkat rumah yang terpasang dengan memberikan kalimat perintah yang ada.

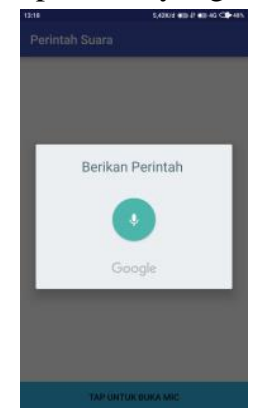

Gambar 8. Halaman Menu Perintah Suara

Pada halaman status sensor pengguna dapat melihat status sensor yang terpasang.

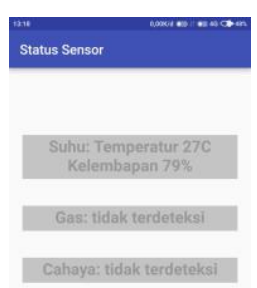

Gambar 9. Halaman Menu Status Sensor
C. Pengujian Antarmuka Aplikasi

TABEL I

TABel Pengujian ANTARMUKa APLIKasi

\begin{tabular}{|c|c|c|c|}
\hline NO & $\begin{array}{l}\text { Jenis } \\
\text { Pengujian }\end{array}$ & $\begin{array}{c}\text { Hasil yang di } \\
\text { harapkan }\end{array}$ & $\begin{array}{c}\text { Hasil } \\
\text { Ekseku } \\
\text { si }\end{array}$ \\
\hline 1 & $\begin{array}{l}\text { Memasukkan } \\
\text { nama pengguna } \\
\text { dan kata sandi } \\
\text { yang terdaftar di } \\
\text { tampilan login }\end{array}$ & $\begin{array}{l}\text { Dapat memasuki } \\
\text { halaman menu utama }\end{array}$ & Berhasil \\
\hline 2 & \begin{tabular}{l}
\multicolumn{2}{l}{ Memasukkan } \\
nama pengguna \\
dan kata \\
yang sandi \\
terdaftar tidak \\
tampilan login
\end{tabular} & $\begin{array}{lr}\text { Tidak } & \text { dapat } \\
\text { memasuki } & \text { halaman } \\
\text { menu utama } & \end{array}$ & Berhasil \\
\hline 3 & $\begin{array}{l}\text { Memilih menu } \\
\text { kendali } \\
\text { perangkat } \\
\text { rumah }\end{array}$ & $\begin{array}{lr}\text { Dapat } & \text { memasuki } \\
\text { menu } & \text { kendali } \\
\text { perangkat rumah }\end{array}$ & Berhasil \\
\hline 4 & $\begin{array}{l}\text { Memilih menu } \\
\text { manual }\end{array}$ & $\begin{array}{l}\text { Menampilkan daftar } \\
\text { perangkat rumah yang } \\
\text { dapat dikendalikan }\end{array}$ & Berhasil \\
\hline 5 & $\begin{array}{l}\text { Memilih } \\
\text { perangkat } \\
\text { rumah yang } \\
\text { ingin di kendali }\end{array}$ & $\begin{array}{lr}\text { Tombol } & \text { perangkat } \\
\text { rumah } & \text { menampilkan } \\
\text { status } & \text { perangkat } \\
\text { rumah } & \text { yang } \\
\text { dikendalikan } & \\
\end{array}$ & Berhasil \\
\hline 6 & $\begin{array}{l}\text { Memilih menu } \\
\text { speech } \\
\text { command }\end{array}$ & $\begin{array}{l}\text { Menampilkan menu } \\
\text { speech command }\end{array}$ & Berhasil \\
\hline 7 & $\begin{array}{l}\text { Memberikan } \\
\text { perintah dengan } \\
\text { speech } \\
\text { command }\end{array}$ & $\begin{array}{lr}\text { Menampilkan } & \text { hasil } \\
\text { perintah } & \text { speech } \\
\text { command } & \end{array}$ & Berhasil \\
\hline 8 & $\begin{array}{l}\text { Memilih menu } \\
\text { status sensor }\end{array}$ & $\begin{array}{l}\text { Menampilkan status } \\
\text { sensor yang terpasang }\end{array}$ & Berhasil \\
\hline 9 & $\begin{array}{l}\text { Memilih menu } \\
\text { logout }\end{array}$ & $\begin{array}{l}\text { Menutup tampilan } \\
\text { menu utama dan } \\
\text { menampilkan menu } \\
\text { login }\end{array}$ & Berhasil \\
\hline
\end{tabular}

Berdasarkan tabel 1 terlihat bahwa semua pengujian yang dilakukan pada antarmuka aplikasi dapat berjalan sesuai hasil yang di harapkan.

\section{Pengujian Fungsi Sensor Suhu}

.TABEL 2

TABEL PENGUJIAN SENSOR SUHU DHT 11

\begin{tabular}{|c|l|l|c|}
\hline NO & Jenis Pengujian & $\begin{array}{c}\text { Hasil yang di } \\
\text { harapkan }\end{array}$ & $\begin{array}{c}\text { Hasil } \\
\text { Ekseku } \\
\text { si }\end{array}$ \\
\hline 1 & $\begin{array}{l}\text { Memberikan panas pada } \\
\text { sensor suhu dht11 }\end{array}$ & $\begin{array}{l}\text { Aplikasi } \\
\text { menampilkan } \\
\text { kondisi suhu }\end{array}$ & Berhasil \\
\hline 2 & $\begin{array}{l}\text { Tidak memberikan } \\
\text { panas pada sensor suhu } \\
\text { dht11 atau membaca } \\
\text { suhu ruangan. }\end{array}$ & $\begin{array}{l}\text { Aplikasi } \\
\text { menampilkan } \\
\text { kondisi suhu }\end{array}$ & Berhasil \\
\hline
\end{tabular}


Berdasarkan hasil pengujian pada tabel 2 dapat ditunjukkan bahwa pengujian sensor suhu dapat berjalan dengan baik dalam mendeteksi suhu ruangan.

\section{E. Pengujian Fungsi Sensor Gas MQ-6}

TABEL 3

TABEl PENGUJiAn SENSOR SUHU MQ-6

\begin{tabular}{|c|l|l|c|}
\hline NO & Jenis Pengujian & $\begin{array}{l}\text { Hasil yang di } \\
\text { harapkan }\end{array}$ & $\begin{array}{c}\text { Hasil } \\
\text { Ekseku } \\
\text { si }\end{array}$ \\
\hline 1 & $\begin{array}{l}\text { Memberikan panas pada } \\
\text { sensor suhu dht11 }\end{array}$ & $\begin{array}{l}\text { Aplikasi } \\
\text { menampilkan } \\
\text { kondisi suhu }\end{array}$ & Berhasil \\
\hline 2 & $\begin{array}{l}\text { Tidak memberikan } \\
\text { panas pada sensor suhu } \\
\text { dht11 atau membaca } \\
\text { suhu ruangan. }\end{array}$ & $\begin{array}{l}\text { Aplikasi } \\
\text { menampilkan } \\
\text { kondisi suhu }\end{array}$ & Berhasil \\
\hline
\end{tabular}

Berdasarkan hasil pengujian pada tabel 3 dapat ditunjukkan bahwa pengujian sensor suhu dapat berjalan dengan baik dalam mendeteksi suhu ruangan.

\section{F. Pengujian Fungsi Sensor Cahaya LDR}

.TABEL 4

TABEl PENGUJIAN SENSOR CAHAYA LDR

\begin{tabular}{|c|l|l|c|}
\hline NO & $\begin{array}{l}\text { Jenis } \\
\text { Pengujian }\end{array}$ & \multicolumn{1}{|c|}{$\begin{array}{c}\text { Hasil yang di } \\
\text { harapkan }\end{array}$} & $\begin{array}{c}\text { Hasil } \\
\text { Ekseku } \\
\text { si }\end{array}$ \\
\hline 1 & $\begin{array}{l}\text { Memberikan } \\
\text { cahaya pada } \\
\text { sensor cahaya } \\
\text { ldr }\end{array}$ & $\begin{array}{l}\text { Aplikasi menampilkan } \\
\text { status sensor cahaya }\end{array}$ & Berhasil \\
\hline 2 & $\begin{array}{l}\text { Tidak } \\
\text { memberikan } \\
\text { cahaya pada } \\
\text { sensor cahaya } \\
\text { ldr }\end{array}$ & $\begin{array}{l}\text { Aplikasi menampilkan } \\
\text { status sensor cahaya dan } \\
\text { mikrokontroler } \\
\text { menghidupkan lampu } \\
\text { halaman }\end{array}$ & Berhasil \\
\hline
\end{tabular}

Berdasarkan hasil pengujian pada tabel 4 dapat ditunjukkan bahwa pengujian sensor cahaya LDR (Light Dependent Resistor) dapat berjalan dengan baik dalam mendeteksi cahaya dan mikrokontroler dapat menghidupkan lampu halaman saat sensor cahaya tidak mendeteksi adanya cahaya.

\section{G. Pengujian Speech Command}

TABEL 5

TABEL PENGUJIAN SPEECH COMMAND

\begin{tabular}{|c|c|c|c|c|c|}
\hline \multirow[t]{2}{*}{ NO } & \multirow{2}{*}{$\begin{array}{l}\text { Jenis } \\
\text { penguji } \\
\text { an }\end{array}$} & \multirow{2}{*}{$\begin{array}{c}\text { Hasil } \\
\text { yang di } \\
\text { harap } \\
\text { kan }\end{array}$} & \multicolumn{3}{|c|}{ Hasil Eksekusi } \\
\hline & & & $\begin{array}{c}\text { Orang } \\
\text { Pertam } \\
\text { a }\end{array}$ & $\begin{array}{l}\text { Orang } \\
\text { Kedua }\end{array}$ & $\begin{array}{l}\text { Orang } \\
\text { Ketiga }\end{array}$ \\
\hline 1 & $\begin{array}{l}\text { Member } \\
\text { ikan } \\
\text { perintah } \\
\text { dengan } \\
\text { kalimat } \\
\text { "buka } \\
\text { pagar", }\end{array}$ & $\begin{array}{l}\text { Aplikasi } \\
\text { berhasil } \\
\text { menamp } \\
\text { ilkan } \\
\text { respon } \\
\text { ucapan } \\
\text { perintah }\end{array}$ & Berhasil & Berhasil & $\begin{array}{c}\text { Berhas } \\
\text { il }\end{array}$ \\
\hline
\end{tabular}

\begin{tabular}{|c|c|c|c|c|c|}
\hline 2 & $\begin{array}{l}\text { Member } \\
\text { ikan } \\
\text { perintah } \\
\text { dengan } \\
\text { kalimat } \\
\text { "buka } \\
\text { depan" }\end{array}$ & $\begin{array}{l}\text { Aplikasi } \\
\text { berhasil } \\
\text { menamp } \\
\text { ilkan } \\
\text { respon } \\
\text { ucapan } \\
\text { perintah }\end{array}$ & Berhasil & Berhasil & $\begin{array}{c}\text { Berhas } \\
\text { il }\end{array}$ \\
\hline 3 & $\begin{array}{l}\text { Member } \\
\text { ikan } \\
\text { perintah } \\
\text { dengan } \\
\text { kalimat } \\
\text { "jangan } \\
\text { buka } \\
\text { pagar" }\end{array}$ & $\begin{array}{l}\text { Aplikasi } \\
\text { berhasil } \\
\text { menamp } \\
\text { ilkan } \\
\text { respon } \\
\text { ucapan } \\
\text { perintah }\end{array}$ & Berhasil & Berhasil & $\begin{array}{c}\text { Berhas } \\
\text { il }\end{array}$ \\
\hline 4 & $\begin{array}{l}\text { Member } \\
\text { ikan } \\
\text { perintah } \\
\text { dengan } \\
\text { kalimat } \\
\text { "tutup } \\
\text { pagar" }\end{array}$ & $\begin{array}{l}\text { Aplikasi } \\
\text { berhasil } \\
\text { menamp } \\
\text { ilkan } \\
\text { respon } \\
\text { ucapan } \\
\text { perintah }\end{array}$ & Berhasil & Berhasil & $\begin{array}{c}\text { Berhas } \\
\text { il }\end{array}$ \\
\hline 5 & $\begin{array}{l}\text { Member } \\
\text { ikan } \\
\text { perintah } \\
\text { dengan } \\
\text { kalimat } \\
\text { "matika } \\
\text { n lampu } \\
\text { depan" }\end{array}$ & $\begin{array}{l}\text { Aplikasi } \\
\text { berhasil } \\
\text { menamp } \\
\text { ilkan } \\
\text { respon } \\
\text { ucapan } \\
\text { perintah }\end{array}$ & Berhasil & Berhasil & $\begin{array}{c}\text { Berhas } \\
\text { il }\end{array}$ \\
\hline 6 & $\begin{array}{l}\text { Member } \\
\text { ikan } \\
\text { perintah } \\
\text { dengan } \\
\text { kalimat } \\
\text { "hidupk } \\
\text { an } \\
\text { lampu } \\
\text { atas" }\end{array}$ & $\begin{array}{l}\text { Aplikasi } \\
\text { berhasil } \\
\text { menamp } \\
\text { ilkan } \\
\text { respon } \\
\text { ucapan } \\
\text { perintah }\end{array}$ & Berhasil & Berhasil & $\begin{array}{c}\text { Berhas } \\
\text { il }\end{array}$ \\
\hline 7 & $\begin{array}{l}\text { Member } \\
\text { ikan } \\
\text { perintah } \\
\text { dengan } \\
\text { kalimat } \\
\text { "hidupk } \\
\text { an } \\
\text { terminal } \\
\text { kamar" }\end{array}$ & $\begin{array}{l}\text { Aplikasi } \\
\text { berhasil } \\
\text { menamp } \\
\text { ilkan } \\
\text { respon } \\
\text { ucapan } \\
\text { perintah }\end{array}$ & Berhasil & Berhasil & $\begin{array}{c}\text { Berhas } \\
\text { il }\end{array}$ \\
\hline 8 & $\begin{array}{l}\text { Member } \\
\text { ikan } \\
\text { perintah } \\
\text { dengan } \\
\text { kalimat } \\
\text { "matika } \\
\text { n } \\
\text { terminal } \\
\text { kamar" }\end{array}$ & $\begin{array}{l}\text { Aplikasi } \\
\text { berhasil } \\
\text { menamp } \\
\text { ilkan } \\
\text { respon } \\
\text { ucapan } \\
\text { perintah }\end{array}$ & Berhasil & Berhasil & $\begin{array}{c}\text { Berhas } \\
\text { il }\end{array}$ \\
\hline 9 & $\begin{array}{l}\text { Member } \\
\text { ikan } \\
\text { perintah } \\
\text { dengan } \\
\text { kalimat } \\
\end{array}$ & $\begin{array}{l}\text { Aplikasi } \\
\text { berhasil } \\
\text { menamp } \\
\text { ilkan } \\
\text { respon }\end{array}$ & Berhasil & Berhasil & $\begin{array}{c}\text { Berhas } \\
\text { il }\end{array}$ \\
\hline
\end{tabular}




\begin{tabular}{|c|l|l|l|l|c|}
\hline & $\begin{array}{l}\text { "tolong } \\
\text { hidupka } \\
\text { n lampu } \\
\text { nya" }\end{array}$ & $\begin{array}{l}\text { ucapan } \\
\text { perintah }\end{array}$ & & & \\
\hline 10 & $\begin{array}{l}\text { Member } \\
\text { ikan } \\
\text { perintah } \\
\text { dengan } \\
\text { kalimat } \\
\text { “tolong } \\
\text { bukakan } \\
\text { saya } \\
\text { pagar" }\end{array}$ & $\begin{array}{l}\text { Aplikasi } \\
\text { berhasil } \\
\text { ilkan } \\
\text { respon } \\
\text { ucapan } \\
\text { perintah }\end{array}$ & & & \\
& & & & \\
\hline
\end{tabular}

Berdasarkan hasil pengujian pada tabel 5 dapat ditunjukkan bahwa aplikasi berhasil menjalankan seluruh perintah yang diterima dari orang pertama, orang kedua, dan orang ketiga dengan tingkat akurasi 100\%.

\section{H. Pengujian Kendali Perangkat Rumah}

TABEL 6

Tabel Pengujian Kendali PerangKat Rumah

\begin{tabular}{|c|c|c|c|}
\hline NO & Jenis Pengujian & $\begin{array}{l}\text { Hasil yang di } \\
\text { harapkan }\end{array}$ & $\begin{array}{l}\text { Hasil } \\
\text { Ekse } \\
\text { kusi }\end{array}$ \\
\hline 1 & $\begin{array}{l}\text { Memberikan perntah } \\
\text { pada aplikasi dengan } \\
\text { jeda waktu } 1 \text { detik } \\
\text { secara beruntun } \\
\text { sebanyak } 5 \text { kali }\end{array}$ & $\begin{array}{l}\text { Perangkat rumah } \\
\text { dapat } \\
\text { memberikan hasil } \\
\text { sesuai perintah } \\
\text { terakhir yang } \\
\text { dikirimkan }\end{array}$ & $\begin{array}{c}\text { Berha } \\
\text { sil }\end{array}$ \\
\hline 2 & $\begin{array}{l}\text { Memberikan perntah } \\
\text { pada aplikasi dengan } \\
\text { jeda waktu } 1 \text { detik } \\
\text { secara beruntun } \\
\text { sebanyak } 10 \text { kali }\end{array}$ & $\begin{array}{l}\text { Perangkat rumah } \\
\text { dapat } \\
\text { memberikan hasil } \\
\text { sesuai perintah } \\
\text { terakhir yang } \\
\text { dikirimkan } \\
\end{array}$ & $\begin{array}{c}\text { Berha } \\
\text { sil }\end{array}$ \\
\hline 3 & $\begin{array}{l}\text { Memberikan perntah } \\
\text { pada aplikasi tanpa } \\
\text { jeda secara beruntun } \\
\text { sebanyak } 5 \text { kali }\end{array}$ & $\begin{array}{l}\text { Perangkat rumah } \\
\text { dapat } \\
\text { memberikan hasil } \\
\text { sesuai perintah } \\
\text { terakhir yang } \\
\text { dikirimkan } \\
\end{array}$ & $\begin{array}{l}\text { Berha } \\
\text { sil }\end{array}$ \\
\hline 4 & $\begin{array}{l}\text { Memberikan perntah } \\
\text { pada aplikasi tanpa } \\
\text { jeda secara beruntun } \\
\text { sebanyak } 10 \text { kali }\end{array}$ & $\begin{array}{l}\text { Perangkat rumah } \\
\text { dapat } \\
\text { memberikan hasil } \\
\text { sesuai perintah } \\
\text { terakhir yang } \\
\text { dikirimkan }\end{array}$ & $\begin{array}{c}\text { Berha } \\
\text { sil }\end{array}$ \\
\hline
\end{tabular}

Berdasarkan tabel 6 terlihat bahwa semua pengujian yang dilakukan dapat berjalan sesuai dengan hasil yang di harapkan.

\section{Pengujian Booting Startup Raspberry Pi 3}

.TABEL 7

Tabel Pengujian BoOting Startup Raspberry Pi 3

\begin{tabular}{|c|l|l|c|}
\hline NO & Jenis Pengujian & $\begin{array}{c}\text { Hasil yang di } \\
\text { harapkan }\end{array}$ & $\begin{array}{c}\text { Hasil } \\
\text { Ekseku } \\
\text { si }\end{array}$ \\
\hline 1 & $\begin{array}{l}\text { Menghitung rata - } \\
\text { rata waktu booting }\end{array}$ & $\begin{array}{l}\text { Mendapatkan } \\
\text { waktu rata - rata }\end{array}$ & $\begin{array}{c}21.6 \\
\text { detik }\end{array}$ \\
\hline
\end{tabular}

\begin{tabular}{|c|c|c|c|}
\hline & $\begin{array}{l}\text { startup Raspberry } \\
\text { Pi } 3 \text { dengan koneksi } \\
\text { internet service } \\
\text { provide Indihome }\end{array}$ & $\begin{array}{l}\text { booting } \quad \text { startup } \\
\text { Raspberry Pi } 3\end{array}$ & \\
\hline 2 & $\begin{array}{l}\text { Menghitung rata - } \\
\text { rata waktu booting } \\
\text { startup Raspberry } \\
\text { Pi } 3 \text { dengan koneksi } \\
\text { internet service } \\
\text { provider Telkomsel }\end{array}$ & $\begin{array}{l}\text { Mendapatkan } \\
\text { waktu rata - rata } \\
\text { booting startup } \\
\text { Raspberry Pi } 3\end{array}$ & $\begin{array}{l}22.7 \\
\text { detik }\end{array}$ \\
\hline 3 & $\begin{array}{l}\text { Menghitung rata - } \\
\text { rata waktu booting } \\
\text { startup Raspberry } \\
\text { Pi } 3 \text { dengan koneksi } \\
\text { internet service } \\
\text { provider Tri }\end{array}$ & $\begin{array}{l}\text { Mendapatkan } \\
\text { waktu rata - rata } \\
\text { booting startup } \\
\text { Raspberry Pi } 3\end{array}$ & $\begin{array}{l}23.7 \\
\text { detik }\end{array}$ \\
\hline 4 & $\begin{array}{l}\text { Menghitung rata - } \\
\text { rata waktu booting } \\
\text { startup Raspberry } \\
\text { Pi } 3 \text { dengan koneksi } \\
\text { internet service } \\
\text { provider Indosat }\end{array}$ & $\begin{array}{l}\text { Mendapatkan } \\
\text { waktu rata - rata } \\
\text { booting startup } \\
\text { Raspberry Pi } 3\end{array}$ & $\begin{array}{l}23.3 \\
\text { detik }\end{array}$ \\
\hline 5 & $\begin{array}{l}\text { Menghitung rata - } \\
\text { rata waktu booting } \\
\text { startup Raspberry } \\
\text { Pi } 3 \text { dengan koneksi } \\
\text { internet service } \\
\text { provider XL }\end{array}$ & $\begin{array}{l}\text { Mendapatkan } \\
\text { waktu rata - rata } \\
\text { booting startup } \\
\text { Raspberry Pi } 3\end{array}$ & $\begin{array}{l}23.1 \\
\text { detik }\end{array}$ \\
\hline
\end{tabular}

Berdasarkan tabel 7 terlihat bahwa rata - rata booting startup yang dibutuhkan Raspberry Pi 3 untuk kembali pada pengaturan sebelum dimatikan adalah 22.8 detik.

\section{J. Pengujian Kompatibilitas Aplikasi}

.TABEL 6

Tabel Pengujian KompatiBilitas APLikasi

\begin{tabular}{|c|c|c|c|c|}
\hline No & $\begin{array}{c}\text { Merek } \\
\text { Perangkat }\end{array}$ & Tipe & $\begin{array}{c}\text { Versi } \\
\text { Sistem } \\
\text { Operasi }\end{array}$ & Hasil \\
\hline 1 & $\begin{array}{c}\text { Xiaomi Mi } \\
6\end{array}$ & $\begin{array}{l}\text { Smart } \\
\text { phone }\end{array}$ & $\begin{array}{c}\text { Android } \\
7.1 .1 \\
\text { (Nougat) }\end{array}$ & $\begin{array}{l}\text { Aplikasi dapat } \\
\text { berjalan } \\
\text { dengan baik }\end{array}$ \\
\hline 2 & Vivo V3 & $\begin{array}{l}\text { Smart } \\
\text { phone }\end{array}$ & $\begin{array}{c}\text { Android } 5.1 \\
\text { (lolipop) }\end{array}$ & $\begin{array}{l}\text { Aplikasi dapat } \\
\text { berjalan } \\
\text { dengan baik }\end{array}$ \\
\hline 3 & $\begin{array}{c}\text { Zenfone } 2 \\
\text { Deluxe }\end{array}$ & $\begin{array}{l}\text { Smart } \\
\text { phone }\end{array}$ & $\begin{array}{c}\text { Android } \\
6.0 .1 \\
\text { (Marshmall } \\
\text { ow) }\end{array}$ & $\begin{array}{l}\text { Aplikasi dapat } \\
\text { berjalan } \\
\text { dengan baik }\end{array}$ \\
\hline 4 & $\begin{array}{c}\text { Lenovo } \\
\text { S820 }\end{array}$ & $\begin{array}{l}\text { Smart } \\
\text { phone }\end{array}$ & $\begin{array}{c}\text { Android } \\
4.4 .2 \\
\text { (Kitkat) }\end{array}$ & $\begin{array}{l}\text { Aplikasi dapat } \\
\text { berjalan } \\
\text { dengan baik }\end{array}$ \\
\hline 5 & $\begin{array}{c}\text { Samsung } \\
\text { Note } 2\end{array}$ & $\begin{array}{l}\text { Smart } \\
\text { phone }\end{array}$ & $\begin{array}{c}\text { Andorid } \\
4.1 .1 \\
\text { (Jelly Bean) }\end{array}$ & $\begin{array}{l}\text { Aplikasi dapat } \\
\text { berjalan } \\
\text { dengan baik }\end{array}$ \\
\hline No & $\begin{array}{c}\text { Merek } \\
\text { Perangkat }\end{array}$ & Tipe & $\begin{array}{c}\text { Versi } \\
\text { Sistem } \\
\text { Operasi }\end{array}$ & Hasil \\
\hline 6 & $\begin{array}{c}\text { Samsung } \\
\text { Duos }\end{array}$ & $\begin{array}{l}\text { Smart } \\
\text { phone }\end{array}$ & $\begin{array}{l}\text { Android } 4.0 \\
\text { (Ice Cream } \\
\text { Sandwich) }\end{array}$ & $\begin{array}{l}\text { Aplikasi tidak } \\
\text { dapat di } \\
\text { pasang }\end{array}$ \\
\hline
\end{tabular}


Berdasarkan tabel 8 terlihat bahwa pengujian aplikasi pada smartphone yang menggunakan Android versi 4.1.1 (Jely Bean) hingga Android versi 7.1.1 (Nougat) dapat berjalan dengan baik. Untuk Pengujian aplikasi pada smartphone yang menggunakan android 4.0 (Ice Cream Sandwich) ke bawah aplikasi tidak dapat pasang.

\section{K. Kesimpulan}

Berdasarkan hasil analisis dan pengujian aplikasi pengendali smarthome menggunakan mikrokontroler berbasis android dengan Speech Recognition, didapat kesimpulan sebagai berikut:

1. Aplikasi dapat mengendalikan perangkat rumah beruntun dan tanpa jeda.

2. Aplikasi dapat menampilkan informasi dari status sensor yang terpasang.

3. Mikrokontroler dapat menghidupkan kipas ketika sensor gas mendeteksi kebocoran gas dan dapat menghidupkan lampu ketika sensor cahaya tidak mendeteksi cahaya.

4. Rata - rata booting startup yang dibutuhkan Raspberry Pi 3 untuk kembali pada pengaturan sebelum dimatikan adalah 22.8 detik

5. Pengendalian perangkat rumah dengan speech command memiliki tingkat akurasi $100 \%$

6. Kompabilitas aplikasi dapat berjalan dari versi android 4.1.1 (Jelly Bean) hingga 7.1.1 (Nougat).

\section{DAFTAR PUSTAKA}

[1] King, N. 2003. What is a Smarthome ?. England: Intertek Research and Testing Centre.Azman, N., dan T. F. Yurmama. 2009. Perancangan Software Aplikasi Pervasive Smart Home. Seminar Nasional Aplikasi Teknologi Informasi . Yogyakarta, tanggal 20 Juni 2009. Yogyakarta.

[2] Brock, J. D. et. al., "Changing the world with a Raspberry Pi," Journal of Computing Science in Colleges Vol. 29 Issue 2 (2013, Dec) $151-153$.

[3] R. E. Sorace, V. S. Reinhardt, and S. A. Vaughn, "High-speed digital-to-RF converter," U.S. Patent 5668 842, Sept. 16, 1997.

[4] Stephanie, 2015. Sistem otomasi lampu pada bangunan publik dengan metode forward chaining. Jurnal Edukasi dan Penelitian Informatika (JEPIN)Volume 1 Nomor 1 tahun 2015.Teknik Informatika Fakultas Teknik Universitas Tanjungpura.

[5] Andayu, Nessa Putri. Perancangan Text To Speech Converter Engine Dalam Pengucapan Kata Berbahasa Arab Sehari - hari. Jurnal Sistem dan Teknologi Informasi (JUSTIN). Volume 1 Nomor 3 tahun 2013.Teknik Informatka Fakultas Teknik Universitas Tanjungpura. 